\title{
COW MILK PRODUCTION AND FARM STABILITY IN AGRARIAN REFORM SETTLEMENTS IN THE SOUTHEAST AMAZON
}

\author{
Taynã Zanderly da Silva Pereira ${ }^{1}$, Paulo Fernando da Silva Martins ${ }^{1}$, Felipe Domingues \\ Nogueira $^{1}$, Amália Gabriela Aguiar Rocha ${ }^{1}$
}

${ }^{1}$ Federal University of Pará. E-mail: taynazand@ hotmail.com, martinspaulo689@gmail.com, felipend@ufpa.br, agr.aguiar@gmail.com

\begin{abstract}
This article analyses the current situation and prospects of the permanence of farmers in cow milk production on their plots in two agrarian reform settlements with different historical contexts located in the Marabá municipality, State of Pará, Brazil. The analysis makes statistical comparisons with single-factor ANOVA to compare strata between groups of farms that do and do not sell milk and Pearson correlation and simple linear regression analysis to evaluate differences among indicators of livestock husbandry activities to identify the best indicator variables for the improvement of productivity and milk sales. Milk production increases when financial credit is present; however, the sale of milk in agrarian reform farms is hampered by the low intensification of this activity and the need for more land to support the herd, which jeopardises the stability of farms and the permanence of family farmers on their lots ends favouring the migration to urban centres.
\end{abstract}

Keywords: Cattle livestock, financial credit, pasture, rural settlement, size farm

\section{PRODUÇÃO DE LEITE E ESTABILIDADE DA EXPLORAÇÃO AGRÍCOLA EM ASSOCIAÇÕES DE REFORMA AGRÁRIA NO SUDOESTE DA AMAZÔNIA}

\section{RESUMO}

Este artigo analisa a situação atual e as perspectivas da permanência dos agricultores na produção de vacas em seus lotes em dois assentamentos de reforma agrária com diferentes contextos históricos localizados no município de Marabá, no Estado do Pará, Brasil. A análise faz comparações estatísticas com ANOVA de um único fator para comparar estratos entre grupos de 
fazendas que não vendem leite e correlação de Pearson e análise de regressão linear simples para avaliar diferenças entre indicadores de atividades de criação de gado para identificar as melhores variáveis de indicadores para a melhoria de produtividade e venda de leite. A produção de leite aumenta quando o crédito financeiro está presente; no entanto, a venda de leite nas fazendas de reforma agrária é dificultada pela baixa intensificação dessa atividade e a necessidade de mais terras para apoiar o rebanho, o que compromete a estabilidade das fazendas e a permanência dos agricultores familiares em seus lotes e favorece a migração para centros urbanos.

Palavras-chave: Bovinos, crédito, pastagem, assentamento rural, tamanho da fazenda

\section{INTRODUCTION}

Special attention has been given to the environmental impact of livestock in several regions and countries around the world (DE VRIES \& DE BOER, 2010; CASTANHEIRA et al., 2010; TEDESCHI, 2017). In the Brazilian Amazon, at beginning of the 1980s, the agricultural frontier advanced as a result of extensive cattle farming. It was especially more intense in the southeastern part of the region according to Veiga et al. (2004) and required an increase in pasture areas over the forest. Large farms are dedicated to meat production, whereas small farms are dedicated to meat and milk production (PIKETTY et al., 2005; PACHOUD et al., 2017).

The small farms, which are occupied by family farmers and migrants from other regions, were established either through incentives in official colonization areas according to Topall (1992) or spontaneously in vacant public forest areas, farms without titles, or unproductive large farms (subject to reoccupation according to Law no. 8,629, established on February 25, 1993), which were divided into lots of up to 200 ha. For these farmers, land occupation corresponds to the development of the farm's life cycle (BROWDER et al., 2008, CALDAS et al., 2007). In the first phase (installation), the lots were deforested for subsistence farming through the slash-and-burn

process, which is characterized by annual crops and fallow periods (RUTHENBERG, 1980; PEDROSO JUNIOR et al., 2008). In a second phase, cattle milk and meat production began, with the progressive installation of pastures until the size of the lot did not permit further expansion of the herd. The farm would then be in crisis, and the farmers would sell their ownership and improvements and move to new inner forest areas as stated by Ozorio de Almeida \& Campari (1995) and Pichón (1997), a process that was classified as the frontier strategy (DE REYNAL et 
al., 1995). This process, which was quite evident until the 1990s, underwent changes following the greater control of deforestation by the state and the creation of programs linked to agrarian reform (FARIAS et al., 2018).

Small-scale farmers account for a majority of the milk produced in the Brazilian Amazon according to Piketty et al. (2005) and represent a form of diversified livestock farming that may contribute to the stability of small farms without necessarily increasing deforestation. In addition, the production of milk and its derivatives contributes to food safety, particularly in the inner area of the region (KNUTH \& VIDAR, 2011).

Farmers cannot sell or transfer their property or title in the settlement areas under penalty of losing their settler rights. Enhancements in technology offer an opportunity to increase productivity and thus to provide stability for cattle farming which is still difficult to achieve for small family producers without financial capital. One possibility for productivity increases is the use of agrarian reform programs, which have performed an important role in the consolidation of settlements according to Mattei (2005) by expanding the volume of resources - particularly credit resources - for rural settlers, thus allowing those settlers to increase their investment capacity and thereby increasing the possibility that a family may remain on its lot.

There is considerable variation in the characteristics of the milk-producing farms in Marabá. This variability is linked not only to farms' locations related to consumer centers as stated by Poccard-Chapuis et al. (2003) but also to those farm internal characteristics according to Machado et al. (2003), including size. Size, in turn, is linked not only to the period of time since settlement installation but also to type of occupation. It is believed that the consolidation of milk production, in addition to ensuring consumption by the families of the farmers themselves, may contribute to the permanence of these farmers presence on their farms, preventing land concentration and advancement into the forest. By increasing the need for workers, these factors may also help mitigate rural migration to urban centers (FERREIRA et al., 2019).

Small family farmers who produce milk in the Marabá municipality (Southeastern Amazon) have increased production by increasing the areas planted. After the state increased its control over deforestation and restricted agrarian reform programs to prevent the sale of lots, farm intensification in milk production became an alternative farming strategy. Considering the implications of the stability of livestock farming to preventing encroachment into forest areas, this 
study seeks to identify the conditions under which Marabá farmers may produce and sell milk as instruments of land use policy.

\section{MATERIAL AND METHODS}

\section{Study Area}

The seat of the Marabá municipality is situated between two large rivers, the Itacaiúnas and the Tocantins, $485 \mathrm{~km}$ to the south of the capital of the state of Pará. The municipality has a surface area of $15,000 \mathrm{~km}^{2}$ and a population density of 13 inhabitants per $\mathrm{km}^{2}$.

The climate, according to the Köppen climate classification, is tropical humid (Am type) and is characterized by a shorter dry season (September to December) and a longer rainy season (DE REYNAL et al., 1995). The municipality obtains the largest share of its gross domestic product (a share corresponding to USD 37.7 million in 2007) from agriculture livestock in the macroregional unit of the southeast portion of the state. In the last agricultural-livestock census, the municipality reported cow's milk production of 9.3 billion $\mathrm{L} / \mathrm{year}^{-1}$, with $77 \%$ of that production originating from farms with up to 200 ha. The average milk production in these farms was $34.3 \mathrm{~L}$ $\mathrm{d}^{-1}, 72 \%$ of which was produced by farms with at least 200 ha in the state and which comprised $77 \%$ of the value produced in the entire country, provided six-days-per-week collection (IBGE, 2012).

To formulate a sample representative of this period, the Settlement Development Plans for all settlements were first analyzed to select two settlements in different localities that presented different historical contexts. One settlement, which is older, was created out of 3,077 ha in vacant public lands in 1988 with 38 farms. The other settlement is newer and was created in 1998, with a surface area of 2,662 ha in a unproductive large farm whose occupation was brokered by INCRA (Brazilian Institute for Settling and Agrarian Reform), which established lot sizes to meet settlers demands; consequently, the farm size of these newer settlement is relatively smaller than the size of the older ones. Both settlements are located approximately $65 \mathrm{~km}$ from the office of the Marabá municipality.

\section{Data Analysis}

The selection of farms in the settlements was based on 30 structured questionnaires (TEFERA et al., 2015; PAPADOPOULOS \& MARKOPOULOS, 2015) for the older settlement 
and 40 for the newer settlement. After the farms were identified, those producing milk (either for family food or for sale) were selected to cover most of the area of each settlement and the diversity of the farms. Twelve farms sell milk, including 10 in the older settlement and 2 in the newer settlement. Sixteen farms do not sell milk, including 6 in the older settlement and 10 in the newer settlement. In the 28 selected farms, the data were collected through a structured questionnaire and the qualitative data were gathered through open interview with the head of each household. Direct observations were also carried out, while participating in farm activities.

ANOVA comparisons (PAPADOPOULOS \& MARKOPOULOS, 2015) were performed a single factor for the strata between the groups of farms (whether or not they sold milk) without agricultural credit and those with agricultural credit. Analyses of linear probability models were conducted through multiple regressions (COHEN et al., 2003) in the total sample of 28 farms to verify the independent variables that best justify the variables that are indicators of milk production, productivity, and amount sold.

The total sample (both with and without the sale of milk) served as the basis for the following tasks: i) studying the productivity and production of milk, which were considered dependent variables; and ii) evaluating the prospects related to the permanence of families on their lots.

The sample comprising 12 farms that sell milk served as the basis to evaluate the conditions related to the sale of milk, which was considered a dependent variable, as well the independent numerical variables and the respective units used to evaluate the production and productivity of milk in farms.

The independent variables of a categorical nature (with a value of zero or one for a response of yes or no, respectively) are used to evaluate the production and productivity of milk in farms, the amount of milk sold and the prospects related to the permanence of families on their lots.

To evaluate the prospects related to the permanence of families on their lots, additional considerations included the following statements of difficulty, expectation, or intention on behalf of the farmer: low milk price, high land price, lack of fencing, lack of pastures, lack of workforce, lack of cowshed, lack of salt, lack of buyers, expectation that growth capacity will be exhausted in 10 years, expectation of incorporating new areas into the lot, expectation of developing other activities, and expectation of being able to remain on the lot. The relationship between credit for milk production on the one hand, and productivity and sale on the other hand, were also evaluated. 


\section{RESULTS AND DISCUSSION}

According to the 2006 census, the average daily production of cow milk by farms in the Marabá municipality was approximately $87.8 \mathrm{~L} \mathrm{~d}^{-1}$ among farms larger than 200 ha, $34.3 \mathrm{~L} \mathrm{~d}^{-1}$ among small farms of up to $200 \mathrm{ha}$, and $29.8 \mathrm{~L} \mathrm{~d}^{-1}$ among farms of up to 100 ha. The production of milk per milked cow varied proportionally from $2.8 \mathrm{~L} \mathrm{~d}^{-1}$ for farms with less than 100 ha to 3.3 $\mathrm{L} \mathrm{d}^{-1}$ for those with more than 200 ha, which dividing the total production by 288 days to express daily production, corresponds to $60 \%$ of the nation's average (IBGE, 2012).

\section{Factors influencing milk production and productivity farms}

The studied farms have operated for an average of 8.5 years, and their size vary from 24.2 to $101.6 \mathrm{ha}$. In the initial phase of cattle farming activity, 12 families stated that they consumed an average of $3.4 \mathrm{l} \mathrm{d}^{-1}$, but none of them could sell milk. In 2009, all families were consuming milk on an average of $4.01 \mathrm{~d}^{-1}$. In that year, among the 28 researched farms, twelve produced an average of $40.9 \mathrm{l} \mathrm{d}^{-1}$, from which they sold an average of $35.7 \mathrm{l} \mathrm{d}^{-1}$. Thus, among the studied farms, all farmers increased their average milk consumption, all began to consume it, and almost half began to sell it.

In 2009, the size of farms that did not sell milk was statistically identical to the size of those that sold milk. However, the farms that did not sell milk had a greater proportion of forested area, less pasture, and a lower percentage of pasture occupation relative to overall size compared to farms that sold milk. The area of annual crops was also identical between those farms that sold milk and those that did not. However, the planting of seasonal crops occurred in $81 \%$ of the farms that did not sell milk and in only $50 \%$ of those that did. There were no statistically significant differences between fallow land and annual crop areas, but the time of cattle farming and age among those that did not sell milk was, on average, 5.5 and 6.5 years less respectively (Table 1).

The farms that did not sell milk had fewer cows and other animals, spent less time milking cows, had a nearly seven-fold lower milk production, and had a more than $50 \%$ lower value for milk production per cow than those that did sell milk (Table 2). 
Table 1. Variables of farms that did and did not sell milk in the Marabá settlements - Pará State, Brazil.

\begin{tabular}{lrrr}
\hline Variables & $\begin{array}{r}\text { Did not sell milk } \\
(\mathrm{n}=16)\end{array}$ & $\begin{array}{r}\text { Did sell milk } \\
(\mathrm{n}=12)\end{array}$ & P-value $^{\text {a }}$ \\
\hline Size of the farm (ha) & 34.5 & 42.4 & 0.3438 \\
Age of the farm (year) & 11.0 & 17.5 & $6.6 \times 10^{-4}$ \\
Time in cattle farming (year) & 6.9 & 12.4 & $2.1 \times 10^{-3}$ \\
Forested area (ha) & 8.4 & 1.0 & $4.49 \times 10^{-3}$ \\
Annual crop area (ha) & 0.9 & 1.5 & 0.153 \\
Fallow land area (ha) & 9.2 & 9.8 & 0.876 \\
Area of perennial crops (ha) & 1.9 & 0.4 & 0.241 \\
Pasture area (ha) & 13.2 & 26.8 & $5.75 \times 10^{-3}$ \\
Ratio of pasture area/farm size & 0.35 & 0.64 & $2.51 \times 10^{-4}$ \\
Milk production ( $\mathrm{L} \mathrm{d}^{-1}$ per farm) & 4.94 & 40.92 & $1.72 \times 10^{-7}$ \\
\hline
\end{tabular}

${ }^{a}$ Values below 0.05 are significant.

Therefore, the characteristics of the farms that did and did not sell milk are different. The increase in the number of cows, the production per cow, and the herd sizes of the farms that did sell milk all indicate an expansion of cattle farming in these farms; this finding is reinforced by the difference in milking time per cow, which was up to $60 \%$ higher in the farms that did sell milk (Table 2).

Table 2. Herd management characteristics of the milk-producing farms that did and did not sell milk in the Marabá settlements - Pará State, Brazil.

\begin{tabular}{|c|c|c|c|}
\hline Variables & $\begin{array}{c}\text { Did not sell } \\
\text { milk } \\
(n=16)\end{array}$ & $\begin{array}{l}\text { Did sell milk } \\
\qquad(\mathrm{n}=12)\end{array}$ & P-value ${ }^{a}$ \\
\hline Number of milked cows (units) & 6.1 & 13.8 & $3.66 \times 10^{-5}$ \\
\hline Herd size (units) & 14.8 & 30.5 & $4.12 \times 10^{-4}$ \\
\hline Milking time per cow ${ }^{b}$ & 0.08 & 0.13 & $8.48 \times 10^{-2}$ \\
\hline Time spent in holding/number of animals $b$ & 0.05 & 0.02 & $3.32 \times 10^{-2}$ \\
\hline Time spent herding/number of animals ${ }^{b}$ & 0.02 & 0.01 & $5.22 \times 10^{-2}$ \\
\hline Milk production $\left(\mathrm{L} \mathrm{d}^{-1}\right)$ & 6.2 & 40.9 & $3.30 \times 10^{-8}$ \\
\hline Milk production per cow $\left(\mathrm{L} \mathrm{d}^{-1}\right)$ & 1.2 & 3.0 & $3.65 \times 10^{-5}$ \\
\hline
\end{tabular}

${ }^{\mathrm{a}}$ Values below 0.05 are significant; ${ }^{\mathrm{b}}$ hour day ${ }^{-1}$.

Even if dairy cattle husbandry in Pará state displays per-cow productivity of only $64 \%$ of national production, the main dairy region (i.e., the southeastern mesoregion) is responsible for $79 \%$ of the state production (EMBRAPA, 2006). However, this difference does not appear to be linked to improvements in feeding conditions through the use of cultivated pastures or the animal genetic profiles. 


\section{COW MILK PRODUCTION AND FARM STABILITY IN AGRARIAN REFORM SETTLEMENTS IN \\ THE SOUTHEAST AMAZON}

Of the farms studied here, $82 \%$ have an area of less than 50 ha. If we consider the data presented by Oliveira \& Almeida (2008), who report that the current average size of the lots in the region settlement projects has been approximately 50 ha, we can conclude size will limit increases in herds and their production levels unless activity intensifies.

Adequate installations and animal quality are important factors for evaluating herd and pasture performance. Therefore, as has been suggested for some time, public policies for credit should provide financial support for small cattle farmers for - above all - infrastructure such as fences, cowsheds, and good-quality herds (MARTINS \& PEREIRA, 2012). Both, farmers who sell and those who do not sell milk, could improve herds, ranch structures and animal management to increase their productivity, and avoid the need to advance into forested areas, thus rendering cattle husbandry viable over the long term. However, in this region, small dairy producers lack technical information and assistance. Despite efforts by institutions such as Embrapa and Federal Universities towards this issue, there remains a large distance between producers demands and these researchers technological responses (EMBRAPA, 2006).

For small agricultural farms in the Southeastern Amazon whose development is closely linked to extensive cattle-husbandry activities with mixed production (meat and milk) and a low technological level, increases in herd size compete for space with agricultural activities, and the improvement of milk production technologies could increase food security (BOSIRE; 2016). In certain contexts, the intensification of cattle production by smaller producers, with a policy of environmental and economic support, could potentially contribute to frontier stabilization (McMANUS et al., 2016).

Cattle farming offers advantages in relation to other activities; currently, cattle farmers have access to public credit investments.

Larger farms have forest areas that are 3.8 times smaller than those of smallest farms (around 50 ha) presented by Oliveira \& Almeida (2008). These authors found deforestation rates of approximately $2.6 \%$ of forested areas per year in agrarian reform settlements in the municipality of Marabá. This rate is related to pastures and similar to those of the municipalities with the greatest deforestation rates in the Amazon, approximately 3\% per year. These values are comparable with those observed in the studied settlements, and we can easily conclude that the expansion of cattle farming on those farms has occurred as a result of advances into forested areas and decreases in crop areas. 
Milk production and productivity are influenced by several variables that are internal and external to farms. Authors have intended to model aspects of diverse farms related to improving dairy production (HANSSON \& FERGUSON, 2011; ZHENG, et al., 2013; FRUSCALSO, et al., 2017). In this case, focus on variables internal to the farms, several multiple linear regression models were run, to explain variations in milk production and productivity. The model that best explained milk production in 2009 is represented by the equation:

$$
\mathrm{y}=-9.1+100.0 \mathrm{TM} / \mathrm{C}+1.2 \mathrm{HS}-0,8 \mathrm{FA}
$$

In which: TM/C is the ratio between the time spent milking and the number of cows. HS is herd size and FA is forest area. This equation 1 has a high level of significance according to the Ftest in ANOVA, thus providing a reasonable explanation of the majority of variation in milk production by the adjusted R2 (Table B1) and showing significant levels for the independent variables (Table B3).

Milk production displayed a negative relationship with a farm forest area; however, there is a positive relationship between milk production and the herd size.

The lack of specialization in milk production manifests itself as a problem, even taking into account that the existence of a dual-purpose herd (meat and milk) may be positive for small producers - i.e., it allows them to have more than one income alternative and to base their production on market conditions (EMBRAPA, 2006). Although the meat and milk production increases in developing countries (DELGADO, 2003; BOSIRE et al., 2016). Muchagata \& Brown (2003) verified in the Brazilian Amazon that compared to specialized systems, a dual-purpose herd may generate lower compensation rates for milk and meat.

The model that best explains the variation in productivity is defined by the following equation:

$$
\mathrm{y}=+2.010-0.346 \mathrm{ICWM}-0.469 \mathrm{RIHC}+0.191 \mathrm{IC}+0.168 \mathrm{MS}(2)
$$

In which: ICWM is the increase in the number of cows that are not being milked, RIHC is the ratio between the increase in herd size and the number of cows, IC is the increase in the number of cows, and MS is the application of mineral salt. This equation has a high level of significance 
and confidence in explaining variations in milk productivity (Table B2) and shows high significance levels for the independent variables (Table B3).

Machado (2000) observed that there is not much variation in cow productivity between farm types in the Marabá region (i.e., between large and small producers or family farmers) because in both cases, productivity was, on average, $3 \mathrm{~L} \mathrm{~d}^{-1}$ per cow, which corresponds to the same value found in this study among farms that sell milk.

A critical point related to the productivity of the dairy herd in the geographic unit of Southeastern Pará State is that although some producers achieve an average of greater than $5 \mathrm{~L} \mathrm{~d}^{-1}$ per cow, the overall average is $2.2 \mathrm{~L} \mathrm{~d}^{-1}$ per cow (GEP, 2007). This low productivity has historically been attributed to the sector limitations, primarily the herd feed, sanitary conditions, and genetic quality (EMBRAPA, 2006).

The lack of infrastructure for dairy-farming development, particularly with respect to cow sanitation and feeding management due to the low technical knowledge of the producers (with the exception of some settlers, i.e., migrants from dairy-farming regions), explains the low productivity of the production systems (EMBRAPA, 2006). However, it is necessary to make some adjustments in the milk production chain, mainly with investments, with no dairy production potential, nothing available in the transportation and energy supply, besides the incentive of the activity through communication.

\section{Factors influencing the milk sales}

The sale of milk at the studied farms was less dependent on productivity and more dependent on production, with a high adjusted R2 and a high significance according to the F-test of ANOVA and the P values of independent variables (Table $\mathrm{C} 1$ ). Considering the differences between the farms that sell milk and those that do not (Tables 1 and 2), it is interesting to identify the factors linked to the production of milk in an amount that, in addition to being consumed by the family, may be sold. Potentially determining factors are linked to infrastructure, management, feed, and herd prophylaxis (EMBRAPA, 2006).

Assessments were made including the status of farms independent numerical variables in 2009 and variables that changed from the beginning to the 2009 situations. The equation that best explains the current quantity of milk sold includes the increase in the herd and the pasture area and is defined by the following equation: 


$$
y=-23.32+1.65 \mathrm{IH}-1.41 \mathrm{IP}+0.84 \mathrm{FS}+1.70 \mathrm{TCF}
$$

Where: IH is the increase in the herd, IP is the increase in the pasture area, FS is the farm size, and TCF is the time involved in cattle farming. This equation has a high significance and explains almost the entirety of the variation in milk production (Table D1), showing high significance levels for the independent variables (Table D2).

According to equation 3 , the amount of time involved in cattle farming, the size of the farm, and the increase in the herd size are all determinant variables for the sale of milk; however, an increase in pasture area is negatively related to sales. The reason for this observation may be that the increases in pasture area were not oriented towards specialization in dairy farming.

\section{Prospects for increases in milk production and sales}

If we wish to evaluate the possibility for farms to increase their production by increasing their pasture areas, we must consider that there is no statistically significant difference in the size of farms among those who did sell and did not sell milk however, area of pasture and time in cattle farming are greater among those who sell milk, whereas forest area is higher among those who do not (Table 1). Because the technical resources used to support the low capacity of extensive livestock farming is approximately 1 animal unit. ha ${ }^{-1}$, such as Veiga et al. (2004) had already observed, and the maximum ratio between the pasture area and the farm area is 0.70 , farms that sell milk are close to the limit of their support capacity, whereas those farms that do not sell milk are at half way to their limits.

Taking into account that on average, the difference in years of operation between the two groups is 6.5 years, and if non-sellers increase their pasture area, we can consider this value of years to be the estimated time required for non-sellers to also reach their limits.

An increase in farm production depends on the result of investments made and is reflected in farmer expectations with respect to the difficulties encountered and their intentions to remain on his lot. Overall, the investment may be evaluated by production conditions and is linked to the quantity and quality of the herd and to the existing infrastructure in terms of fences, cowsheds, and other installations. 


\section{COW MILK PRODUCTION AND FARM STABILITY IN AGRARIAN REFORM SETTLEMENTS IN \\ THE SOUTHEAST AMAZON}

The most relevant characteristics of the productive structure of farms with and without milk sales are linked to the substitution of forested areas by pastures, infrastructure (fencing and cowsheds), application of salt, and increases in herd size and number of cows milking, which were all larger for farms that sell milk (Table 3).

On average, the decrease in forested area was 37.4 ha among those farms that did sell milk, which is equal to $88 \%$ of the size of those farms (Table 3). This decrease was much lower among non-sellers; however, the decrease was still relatively high (56\% of farm size). Moreover, the increase in pasture area was doubled among those that did sell milk, which justifies the search for methods of expanding support capacity that could allow for herd expansion. To halt deforestation on the agricultural frontier, it is necessary to sustainably intensify production, which requires a redesign of the agricultural technologies developed and made available to farmers as identification of good instruments of land use policy.

Table 3. Relevant elements to the productive structure for farms that do and do not sell milk in the Marabá settlements - Pará State, Brazil.

\begin{tabular}{|c|c|c|c|}
\hline Variables & $\begin{array}{l}\text { Did not sell } \\
\text { milk }(n=16)\end{array}$ & $\begin{array}{c}\text { Did sell milk } \\
\quad(n=12)\end{array}$ & $\mathrm{P}$ value $^{\mathrm{a}}$ \\
\hline Decrease in forested area (ha) ${ }^{b}$ & 19.3 & 37.4 & $5.7 \times 10^{-2}$ \\
\hline Increase in pasture area (ha) ${ }^{b}$ & 13.2 & 26.6 & $6.8 \times 10^{-3}$ \\
\hline Amount of fencing $(\mathrm{km})$ & 1.4 & 2.2 & $3.0 \times 10^{-3}$ \\
\hline Cowshed size $\left(\mathrm{m}^{2}\right)$ & 96.6 & 252.9 & $9.8 \times 10^{-3}$ \\
\hline Quality of cowshed material & 0.31 & 0.67 & $6.6 \times 10^{-2}$ \\
\hline Existence of cowshed cover & 0.68 & 1.00 & $3.3 \times 10^{-2}$ \\
\hline Quality of cowshed cover material & 0.31 & 0.92 & $6.6 \times 10^{-4}$ \\
\hline Application of mineral salt ${ }^{c}$ & 1.9 & 4.9 & $5.3 \times 10^{-3}$ \\
\hline Application of common salt ${ }^{\mathrm{c}}$ & 3.8 & 10.8 & $7.3 \times 10^{-4}$ \\
\hline Increase in cow milking (units) ${ }^{b}$ & 1.7 & 8.8 & $4.5 \times 10^{-10}$ \\
\hline Increase in herd (units) ${ }^{b}$ & 11.3 & 24.1 & $4.9 \times 10^{-3}$ \\
\hline
\end{tabular}

The difference in the amount of fencing indicates the difference in infrastructure that exists between the groups, which is reinforced by the smaller amount of time that the farms that sell milk have available to dedicate to the activities of handling and herding their animals (Table 2).

Farmers who sell milk spend a greater amount of time milking cows, compared to those who do not sell. In addition, farms who sell milk spend 2.8 times more common salt and 2.6 times more mineral salt, than those farmers who do not sell milk (Table 3). Thus, it can be assumed that 
cows that eat mineral salt receive much better nutrition, produce more milk, and need to be milked for longer periods.

The lack of feed formulations and mineral supplements for the Amazon specific conditions, have important consequences for animal reproduction and milk production and these conditions, taken together, lead directly to mineral deficiencies.

There was no significant relationship between the existence of agricultural credit and the sale of milk, productivity, or production increase since the beginning of a farm, but there was a significant relationship between agricultural credit and current production (Table 4).

Credit corresponds to greater milk production, which is nearly three times greater among the group of farmers with credit. As mentioned in the previous discussion, productivity is most strongly influenced by variables related to the number of cows, whereas sales are related to farm size, the time involved in the activity, and the number of animals in the herd.

Table 4. Relationship between credit and milk production and productivity and sales in the Marabá farms - Pará State, Brazil.

\begin{tabular}{lccc}
\hline Variables & $\begin{array}{c}\text { Without credit } \\
(\mathrm{n}=9)\end{array}$ & $\begin{array}{c}\text { With credit } \\
(\mathrm{n}=19)\end{array}$ & P value ${ }^{\mathrm{a}}$ \\
\hline Current milk production $(2009)\left(\mathrm{L} \mathrm{d}^{-1}\right)$ & 9.4 & 26.6 & $3.98 \times 10^{-2}$ \\
Increase in milk production $\left(\mathrm{L} \mathrm{d}^{-1}\right)^{\mathrm{b}}$ & 8.8 & 24.1 & $6.13 \times 10^{-2}$ \\
Current productivity $(2009)\left(\mathrm{L} \mathrm{d}^{-1}\right)$ & 1.8 & 2.0 & 0.7281 \\
Current milk sales $\left(\mathrm{L} \mathrm{d}^{-1}\right)$ & 6.4 & 19.4 & 0.1372 \\
\hline
\end{tabular}

${ }^{\mathrm{a}}$ Values below 0.05 are significant; ${ }^{\mathrm{b}}$ the increase refers to the period from the beginning of the farm until 2009.

In the studied farms, compatible values were not found for the sale of animals and calves, which denotes not only a clear intention to specialize in meat production by those that do not sell milk but also an absence of this intention among those that do sell milk. Both groups seek to make milk production and the sale and exchange of young and adult animals compatible not only with family cash flow needs but also with family needs in times of crisis and illness. The farmers use their animals as a type of savings, whose liquidity is relatively rapid and who have the advantage of self-transportation - i.e., although a sale may not occur immediately, the farmer will be able to keep the animal without suffering a loss (PIKETTY et al., 2005).

The productivity of the work in cattle husbandry is greater than that in annual crops, and the increase in herd size, as a reserve asset, provides greater stability to the farm , optimizes family 
work and makes it possible to enter the path of asset accumulation (HURTIENNE, 2005). The cattle of the eastern Amazon may be considered a more rapid way of accumulating assets, or "livestock", allowing the farmers opportunities to invest in other projects in the future, such as new agricultural activities that demand a significant amount of capital (SIEGMUND-SCHULTZE et al., 2010).

The differences between declared difficulties associated with the management of farms that do not sell milk and those that do were the low price of milk and the high cost of land. Meanwhile, farmers expectations of remaining on their lots were significantly greater among farmers who do not sell milk (Table 5).

Table 5. Relevant variables declared by farmers with respect to difficulties and intention to remain on farms with and without milk sales in the Marabá settlements - Pará State, Brazil.

\begin{tabular}{lccc}
\hline Variables & $\begin{array}{c}\text { Did not sell milk } \\
(\mathrm{n}=16)\end{array}$ & $\begin{array}{c}\text { Did sell milk } \\
(\mathrm{n}=12)\end{array}$ & P value $^{\mathrm{a}}$ \\
\hline Low price of milk & 0.50 & 1.00 & $3.5 \times 10^{-2}$ \\
High cost of land & 0.00 & 0.25 & $2.6 \times 10^{-3}$ \\
Expectation to remain on lot & 1.00 & 0.75 & $3.5 \times 10^{-2}$ \\
\hline
\end{tabular}

${ }^{\mathrm{a}}$ Values below 0.05 are significant.

The higher number of farms that both sell milk and note the low price of milk and the high cost of land appears to be suggestive of the expectation of a herd expansion among these farms, with the goal of increasing production and income. The studied farms can only achieve a production increase, under current conditions, through an intensification of land use, because of their limitations in farm and pasture size. The lower expectation of remaining on the lot declared by the farmers who sell milk may indicate that they do not plan to increase income through an increase in production but instead that they intend to leave their lots.

The studies performed by De Reynal et al. (1995), conducted prior to the developments resulting from the creation of the settlements and settler support programs as observes Mattei (2005), describe farm crises related to pastures. Under current conditions, this situation has changed little, particularly for farms that sell milk, because these farms are still characterized by a difficulty in increasing herd size, which was also true during the period of the frontier strategy.

Some changes were observed at the oldest location in the present study, at which there were at least four cases of credit for the recovery of pasture areas through mechanization involving the preparation of the area at a deeper level and the use of phosphate fertilization. At both settlements, 282 
cows were even being raised for dual purposes. However, the credit for cattle farming made available to those farmers was primarily for herd acquisition and did not consider other important factors identified by Embrapa (2005), such as installations, access to technical assistance, and incentives to create networks for product transformation and trading.

\section{CONCLUSION}

In Southeastern Amazonian farms on agrarian reform settlements, milk production is directly related to the ratio of milking time to cows, herd size, and a decrease in forested area, whereas milk productivity is associated to an increase in cows and the application of mineral salt. Productivity is low due to a lack of structure, adequate management, and improved animals.

Farms that sell milk are older, have more experience cattle farming, and have increased their herd size more than those that do not sell milk. Thus, these farms have larger pastures and have decreased their forested area more than farms that do not sell milk. In contrast, the determinant variables for milk sales are time elapsed since the beginning of cattle farming, farm size, and increase in herd size.

Credit displayed a relationship with production but not with productivity or milk sales. Under the current conditions of cattle farming, farms that sell milk cannot expand production through an increase in pasture area, and therefore, their option is to intensify their land use.

Those farms that do not sell milk may remain as such for a while, but cattle farming for self-consumption only is financially unsustainable. Intensification of labor and land use are necessary to reach the economic potential of either dairy or meat production Otherwise, it will be difficult to meet the needs of the family throughout its life cycle.

There is no clear strategy for specialization in dairy farming or meat production by farmers who sell milk and those who do not, and both groups seek to make milk production compatible with the sale of calves and adult animals.

In current situation of agrarian reform settlements an increase in production standards is only possible for farms through pasture expansion, which is limited by legislation that prevents deforestation and by the impossibility of expanding lot sizes. Although milk production may be higher on farms with better installations and larger herd sizes, there are no differences in productivity, meaning that investments in technology and herd quality are needed so that milk production may provide stability to those farms. 


\section{ACKNOWLEDGEMENTS}

We recognize the Coordination of Improvement of Personal Higher Education (CAPES)

for the scholarship that it granted to the first author of this study. Special thanks also go to Noemi

Sakiara Porro for her help in improving the manuscript.

\section{REFERENCES}

BOSIRE, C. K.; KROL, M. S.; MEKONNEN, M. M.; OGUTU, J. O.; DE LEEUW, J.; LANNERSTAD, M.; HOEKSTRA, A. Y. 2016. Meat and milk production scenarios and the associated land footprint in Kenya. Agricultural Systems, s/1, v. 145, p. 64-75.

BROWDER, J O.; PEDLOWSKI, M A.; WALKER, R.; WYNNE, R. H.; SUMMERS, P. M.; ABAD, A.; BECERRA-CORDOBA, N.; MIL-HOMENS, J. 2008. Revisiting theories of frontier expansion in the Brazilian Amazon: A survey of the colonist farming population in Rondonia's post-frontier, 1992-2002. World Development, s/1, v. 36, p.1469-1492.

CALDAS, M.; WALKER, R.; ARIMA, E.; PERZZ, S.; ALDRICH, S.; SIMMONS, C. 2007. Theorizing Land Cover and Land Use Change: The Peasant Economy of Amazonian Deforestation. Annals of the Association of American Geographers, s/1, v. 97, p. 86-110.

CASTANHEIRA, É. G.; DIAS, A. C.; ARROJA, L.; AMARO, R. 2010. The environmental performance of milk production on a typical Portuguese dairy farm. Agricultural Systems, s/1, v. 103, p. 498-507.

COHEN, J., COHEN, P., WEST, S. G.; AIKEN, L. S. 2003. Applied multiple regression correlation analysis for the behavioral sciences. Mahwah; London: LAWRENCE ERLBAUM ASSOCIATES, PUBLISHERS (3rd ed.). 643p.

DELGADO, C.L., 2003. Rising consumption of meat and milk in developing countries has created a new food revolution. Journal of Nutrition. s/l, v.133, n. 11, p. 3907-3910 (Supplement).

DE REYNAL, V.; MUCHAGATA, M. G.; TOPALL, O.; HÉBETTE, J. 1995. Agriculturas familiares e desenvolvimento em frente pioneira amazônica (Family Farming and Development at the Amazonian Pioneer Front). Belém, Universidade Federal do Pará. 69 p.

DE VRIES, M.; DE BOER, I. J. M. 2010. Comparing environmental impacts for livestock products: A review of life cycle assessments. Livestock Science, s/1, v.128, p. 1-11.

EMBRAPA. 2006. Criação de gado leiteiro na Zona Bragantina. Sistemas de produção (Dairy cattle in Bragantina area. Production systems). Embrapa Amazônia Oriental, Belém. 149 p.

FARIAS, M.; BELTRÃO, N. E. S.; CORDEIRO, Y, E. M.; SANTOS, C. A. 2018. IMPACT OF RURAL SETTLEMENTS ON THE DEFORESTATION OF THE AMAZON. Mercator, Fortaleza, v. 17. p. 1-20.

FERREIRA, G. M. V.; ENDE, M. V.; ROSSÉS, G. F.; NEUMANN, P. S. 2019. O cooperativismo como estratégia de inserção dos assentados da reforma agrária nos mercados dinâmicos: o caso da COPERTERRA. Revista de Administração da UFSM, s/l, v. 11, n. 5, p. 1164-1181.

FRUSCALSO, V.; ANTILLON, G. O.; HOTZEL, M. J. 2017. Smallholder family farmers' perceptions, attitudes and choices regarding husbandry practices that influence performance and welfare of lactating dairy calves. Cienc. Rural, Santa Maria, v. 47, n. 11.

GEP - Governo do Estado do Pará (Government of Pará State). 2007. Plano de desenvolvimento da atividade leiteira das Regiões Sul e Sudeste do Pará (Development plan of dairy farming 
in the South and Southeast of Pará State). Secretaria de Estado de Desenvolvimento, Ciência e Tecnologia, Belém. 91 p.

GOODMAN, D. E.; SORJ, B.; WILKINSON, J. 1985. Agroindústria, políticas públicas e estruturas sociais rurais: análises recentes sobre a agricultura brasileira (Agribusiness, rural social structures and public policies: recent analyzes of Brazilian agriculture). Revista de Economia Política, São Paulo, v. 5, p. 31-56.

HANSSON, H.; FERGUSON, R. 2011. Factors influencing the strategic decision to further develop dairy production - A study of farmers in central Sweden. Livestock Science, s/l, v. 135, p. 110-123.

HURTIENNE, T. 2004. Análise socioeconômica dos sistemas de uso de terra por pequenos produtores agrários na Amazônia oriental (Socioeconomic analysis of land use by small agricultural producer systems in Eastern Amazon). Novos cadernos do NAEA, Belém, v. 7, p. 191-272.

HURTIENNE, T. 2005. Agricultura familiar e desenvolvimento rural sustentável na Amazônia (Family farming and sustainable rural development in the Amazon). Novos cadernos do NAEA, Belém, v. 8, p. 19-71.

IBGE - Brazilian Institute of Geography and Statistics. 2012. Automatic Recovery System SIDRA, Table 933, Rio de Janeiro, Brazil.

KNUTH, L.; VIDAR, M. 2011. Constitutional and Legal Protection of the Right to Food around the World. Food and Agriculture Organization of the United Nations. 36 p.

MACHADO, R. C. 2000. Estudos dos sistemas de criação através da abordagem das práticas: o caso dos bovinos leiteiros da agricultura familiar, na Micro Região de Marabá (Study of cattle-raising systems through practice approach: the case of dairy cattle in family farming, in Marabá Micro Region of Para State, Brazil). Master thesis. Amazonian Agriculture. Universidade Federal do Pará, Belém, 181 p.

MACHADO, R. C.; MUCHAGATA, M. R. G.; SILVA, W. R. 2003. Modelização e viabilidade da pecuária na agricultura familiar da fronteira agrícola (Modeling and viability of livestock on family farms of the agricultural frontier). In: TOURRAND, J. F.; VEIGA, J. B.; editors. Viabilidade de sistemas agropecuários na agricultura familiar da Amazônia, Embrapa Amazônia Oriental, Belém, p. 373-411.

MARTINS, P. F. S.; da S. PEREIRA, T. Z. 2012. Cattle-raising and public credit in rural settlements in Eastern Amazon. Ecological Indicators, s/1, v. 20, p. 316-323.

MATTEI, L. 2005. Impactos do Pronaf. Análise dos indicadores. Ministério do Desenvolvimento Agrário, Brasília. 71 p.

McMANUS, C.; BARCELLOS, J. O. J.; FORMENTON, B. K.; HEMUCHE P. M.; CARVALHO, O. A.; GUIMARÃES, R. F.; GIANEZINI, M.; DIAS, E. A.; LAMPERT, V.N.; ZAGO, D., BRACCINI NETO, J. 2016. Dynamics of cattle production in Brazil. Plos One, San Francisco and Cambridge. 11, n. 1.p. 1-15.

MUCHAGATA, M.; BROWN, K. 2003. Cows, colonists and trees: rethinking cattle and environmental degradation in Brazilian Amazonia. Agricultural Systems, s/l, v.76, p. 797816.

OLIVEIRA, M. C. C.; ALMEIDA, J. 2008. Mudanças sociais e formas de exploração do meio natural em áreas de fronteira agrária amazônica: o caso da região de Marabá - PA. In: $3^{\circ}$ Encontro da Rede de Estudos Rurais, Campina Grande, Universidade do Rio Grande do Sul. OZORIO, de A. A. L.; CAMPARI, J. S. 1995. Sustainable settlement in the Brazilian Amazon. Oxford University Press, New York, 189 p. 
PACHOUD, C.; POCCARD-CHAPIUS, R; BONAUDO, T.; TOURAND, J-F.; MAURICIO, R. M. 2017. Energy Analysis and Measurement of the Greenhouse Gas Emissions of Livestock Systems. A Comparison of Different Livestock Systems in the Eastern Brazilian Amazon. Journal of Agriculture and Environmental Sciences, s/1, v. 6, n. 1, p. 30-37.

PAPADOPOULOS, S.; MARKOPOULOS, T. 2015. Factors affecting the implementation of integrated agriculture in Greece. Procedia Economics and Finance. s/l v. 33 p. 269 - 276.

PEDROSO JUNIOR, Nelson Novaes; MURRIETA, Rui Sérgio Sereni; ADAMS, Cristina. 2008. A agricultura de corte e queima: um sistema em transformação. Boletim do Museu Paraense Emílio Goeldi. Ciências humanas, Belém, v. 3, n. 2, p. 153-174.

PICHÓN, F. J. 1997. Settler households and land-use patterns in the Amazon frontier: farm-level evidence from Ecuador. World Development, s/l, v. 25, p. 67-91.

PIKETTY, M. G.; VEIGA, J. B., TOURRAND, J. F.; ALVES, A. M. N.; POCCARD-CHAPUIS, R.; THALES, M. 2005. Les déterminants de 1' expansion de 1' élevage bovin en Amazonie orientale: Conséquences pour les politiques publiques. Cadernos de Ciência e Tecnologia, Brasilia, v. 22, p. 221-234.

POCCARD-CHAPUIS, R.; VEIGA, J. B., PIKETTY, M. G.; FREITAS, C. M. K. H.; TOURRAND, J. F. 2003. A cadeia produtiva do leite: Uma alternativa para consolidar a agricultura familiar nas frentes pioneiras da Amazônia? In: TOURRAND, J. F.; VEIGA, J. B.; editors. Viabilidade de sistemas agropecuários na agricultura familiar da Amazônia (Feasibility of Agricultural Systems in Family Farming in the Amazon). Embrapa Amazônia Oriental, Belém, p. 355-372.

RUTHENBERG, H. 1980. Farming systems in the tropics. Oxford University Press, Oxford, 423 p.

SIEGMUND-SCHULTZE, M.; RISCHKOWSKY, B.; VEIGA, J. B.; KING, J. M. 2010. Valuing cattle on mixed smallholdings in the Eastern Amazon. Ecological Economics, s/1, v. 69. p. 857- 867.

TEDESCHI, Luis Orlindo et al. 2017. A glimpse of the future in animal nutrition science. 1. Past and future challenges. Revista Brasileira de Zootecnia, Viçosa, v. 46, n. 5, p. 438-451.

TEFERA M.; DEMEL T.; HULTÉN, H., and YEMSHAW Y. 2015. The Role of Communities in Closed Area Management in Ethiopia. Mountain Research and Development, s/1, v. 25, n. 1, p. 44-50.

TOPALL, O. 1992. O sistema de criação de bovinos nos lotes da colonização oficial da transamazônica, região de Marabá, In: Actes du Séminaire Agriculture Paysanne et Développement Rural en Amazonie Orientale, Université Federal du Pará, Université des Antilles et de la Guyane, Belém, p. 203-226.

VEIGA, J. B.; TOURRAND, J. F.; PIKETTY, M. G.; POCCARD-CHAPUIS, R.; ALVES, A. M.; THALES, M. C. 2004. Expansão e trajetórias da pecuária na Amazônia (Expansion and trajectory of cattle-raising in the Amazon), Editora Universidade de Brasília, $161 \mathrm{p}$.

ZHENG, C.; LIU, Y.; BLUEMLING, B.; CHEN, J.; MOL, A. P. J. 2013. Modeling the environmental behavior and performance of livestock farmers in China: an ABM approach. Agricultural Systems, s/l, v.122, p. 60-72. 